\title{
A Study on the Postmodern Narrative Features in Toni Morrison's Song of Solomon
}

\author{
Miaomiao WANG ${ }^{1} \&$ Chengqi LIU ${ }^{1}$ \\ ${ }^{1}$ North China Electric Power University, Beijing, China \\ Correspondence: Chengqi LIU, North China Electric Power University, Beijing, China. E-mail: \\ 2472534033@qq.com
}

Received: June 1, 2021

Accepted: July 7, $2021 \quad$ Online Published: July 15, 2021

doi:10.5539/ells.v11n3p28

URL: https://doi.org/10.5539/ells.v11n3p28

\begin{abstract}
Toni Morrison (1931-2019) is renowned as the Nobel and Pulitzer Prize-winning American novelist. Her third novel Song of Solomon was written in the context of postmodernism, which embodies a variety of postmodern narrative features. Postmodern works are frequently inclined to ambiguity, anarchism, collage, discontinuity, fragmentation, indeterminacy, metafiction, montage, parody, and pluralism. Such postmodern narrative features as parody, metafiction and indeterminacy have been manifested in Song of Solomon. In this novel, Toni Morrison employs the strategy of parody in order to subvert traditional narrative modes and overthrow the western biblical narrative as well as African mythic structure. Meta-narratives are also used in the text to dissolve the authority of the omniscient and omnipotent narrator. By questioning and criticizing the traditional narrative conventions, Morrison creates a fictional world with durative indeterminacy and unanswered problems. Through presenting parody, metafiction and indeterminacy, this paper attempts to analyze the postmodern narrative features in Song of Solomon and further explore Morrison's writing on the African-American community and its future development.
\end{abstract}

Keywords: Toni Morrison, Song of Solomon, postmodern narrative features

\section{Introduction}

Toni Morrison was the first African-American novelist to win the Nobel Prize in Literature in 1993. Morrison has been brought into international attention since the publication of Song of Solomon in 1977. Since the 1980s, western scholars began to pay great attention to Song of Solomon which won the National Book Critics Circle Award, exploring the cultural identity of characters, African-American culture, narrative features and so on. With regard to the African-American literary tradition, Morrison's Song of Solomon presents the "complexities of Afro-American life, history, and culture through her creation of a revolutionary group called the Seven Days" (Story, 1989, p. 150). As for the narrative structure of this novel, some scholars think that Morrison intermingles "an ancient, oral storytelling genre with a modern literate one" (Middleton, 1993, p. 74). Unlike the foreign critics, Chinese scholars started to study this novel in 1990s. Throughout the journals indexed by CNKI, researchers mainly centre on the following aspects: the theme of African-American literature, literary techniques and so on. About the thematic studies on Song of Solomon, Xu Wenpei discusses "the estranged relationships" (Xu, 2003, p. 152). On the writing technique of Song of Solomon, a study shows that "Morrison expresses her own views of history and thoughts to real life, and intonates a 'Song of Solomon' belonging to African American, especially to African American women" (Tang, 2004, p. 174).

In addition, on the postmodern narrative elements in Song of Solomon, Hu jie states that "besides the narrative authority of omniscient narrator, the closure structure of circular narrative has also been undercut" (Hu, 2013, p. 107). Guo Lifeng and Yang Xiaoli have given a more detailed interpretation of one of the postmodern narrative features, that is, parody. They remark that "Morrison places the experiences of the Black marginalized group in the narrative center under the superficial submission to and identification with the Bible, by allusions to Biblical stories, characters, images and themes" (Guo \& Yang, 2017, p. 69). Regarding Morrison's use of western myths, Harris argues that she thereby "turns to myth to underpin her narrative, but does so without transforming her novel into pure fantasy or overloading her story with literary allusions" (Harris, 1980, p. 69). In a word, there is still room for analyzing the postmodern narrative features in Song of Solomon.

It is widely accepted that "postmodernism deems that in the world today the important functions of such various 
phenomena as instability, indeterminacy, discontinuity, disorder, rupture, sudden changes, etc. have been more and more recognized and paid great attention to" (Chen \& Qu, 2013, p. 346). The writing techniques of modern fictions such as the disorder of time and space, symbolism, stream-of-consciousness, etc. have been relegated to the secondary position in postmodern fictions. Postmodernism views that the world is "no longer a world of totality but rather one of plurality, fragmentation, and decentralization" (Wang, 2013, p. 246). In A Poetics of Postmodernism: History, Theory, Fiction, Linda Hutcheon, a theorist of postmodernism, argues that, "in most of the critical work on postmodernism, it is narrative - be it in literature, history, or theory - that has usually been the major focus of attention" (Hutcheon, 1988, p. 5). Some literary terms in postmodern writing are "usually accompanied by a grand flourish of negativized rhetoric: we hear of discontinuity, disruption, dislocation, decentring, indeterminacy, and antitotalization" (Hutcheon, 1988, p. 3).

Based on the above ideas, my present analysis of the novel concentrates on the postmodern narrative features, including parody, metafiction, and indeterminacy. Morrison parodies the Bible and black folktales to subvert dominant white Christian values and destroy the reader's dependence on an absolute truth. As a typical metafiction, Song of Solomon focuses more on the fictionality instead of following a clear plot and the usual development of traditional novels. The authority of an omniscient narrator or writer begins to falter. Moreover, it is just indeterminacy that unfolds the essence and spirit of the postmodern narrative, which can be found in this novel.

\section{Parody: To Subvert the Traditional Narrative Conventions}

Parody, used by many postmodern novelists, is often regarded as a literary method to stress the weakness of imitation objects. Linda Hutcheon argues that "parody is a perfect postmodern form" (Hutcheon, 1988, p. 11). Some people think "Hutcheon presents parody as a quintessentially ironic mode" (Shirvani, 1994, p. 295). As Hutcheon comments, "women and Afro-American artists' use of parody to challenge the male white tradition from within, to use irony to implicate and yet to critique, is distinctly paradoxical and postmodernist" (1988, p. 11).

Naming holds a special significance in Song of Solomon whose main roles' names are bizarre. Almost each character has a biblical name, but their personalities or experiences are completely contrary to the archetypal images. Pilate does not have the same characteristics as her namesake. The latter has become a symbol of power and strength in the Bible, but Pilate is not cruel in authority. Pilate takes herself into a higher position through working her way up from laundrywoman to entrepreneur. She completes her journey without being aided by supernatural powers from others. As the above mentioned, it can be found that Pilate is a brave woman who is fully responsible for her own life, which largely differentiates from the namesake in the Bible. "Pilate's peculiar name is not the only name of the novel taken from the Bible" (Farshid, 2015, p. 332). Hagar, a biblical name, is an explicit explanation of her nervous and desperate relationship with her lover Milkman who rejects her. However, unlike the tragedy of Hagar in Song of Solomon, her namesake of the Bible is ultimately rescued from the desert.

What's more, Guitar, Milkman's best friend in the past, attempts to kill Milkman who is suspected of cheating him out of hidden gold. Guitar plans to use this wealth to fund the Seven Days group's revenge for the killing of blacks. In the Bible, God spends seven days in creating the world and vitalizing all living things. Far from God's love and benevolence, the organization named Seven Days is a racist revenge group aimed at killing. It can be seen that the distinction or distortion of biblical images is actually a kind of parody and mockery of western Christian culture, suggesting that the Bible is not a spiritual belief of African-Americans who are oppressed by the white community.

Additionally, the description of black and white colors in the novel subverts the traditional narrative convention of linking white with good, black with evil. In Song of Solomon, the white characters are represented as a symbol of violence. Guitar's mother is given forty dollars by a white man for his father's body, suggesting how much a black person is considered to be worth. The employer of Corinthian, who is also white, doesn't treat her employee as an equal, even though she claims to hold liberal views towards the black and the white. A white bull is used by Freddie to describe his mother's death, while the white peacock chased by Milkman and Guitar symbolizes greed.

Another paradox in the novel is that, "Milkman finds himself by going back into the past, but he does not stay there; he takes what will serve him and leaves" (Blake, 1980, p. 82). Similarly, Morrison returns to a folktale but only takes the part that accords with her feeling of contemporary reality. It is known that the "song of Solomon" is a different version of a tale of the flight of African-born slaves. "The difference between the song of Solomon and the common components of the story of the flying Africans dramatizes the difference between the world of 
the black folk consciousness and Toni Morrison's fictional world" (Blake, 1980, p. 82). It appears that, by imitating and mocking the Bible or black folktale, parody makes this imitation and mockery very interesting through the incongruity between the form, style and ridiculous themes of the work or the genre.

Overall, parody can be used as a way to subvert the traditional narrative conventions. Through the way of satirizing, Morrison reveals the relationship between the mainstream culture and the marginal culture, and then explores the future development of African-Americans.

\section{Metafiction: To Eliminate the Authority of an Omniscient Narrator}

Since the 1960s, people have paid great attention to how to contemplate, how to depict, and how to disseminate the knowledge about their social experiences. It is metafiction that tries to answer these questions by examining the fictional form itself. For postmodern writers, metafiction is used to doubt the traditional fictional form and the structure of narrative. In short, metafiction aims to explore the connection between fiction and the reality, and to reveal the usual practice of the traditional fiction through self-exploration. In order to establish herself as the author, Toni Morrison implements disintegration towards the narrator's moral and cognitive authority. In traditional novels, the omniscience narrator, like God, can perceive the inner thoughts of each person and make authoritative judgments on every event. But the narrator of Song of Solomon becomes conflicting. Sometimes, she provides an authoritative explanation of an issue from one perspective and suddenly abandons the problematic perspective to turn to another perspective from which she explains again. The narrator's incoherent attitude challenges readers who expect the truth, which can be best illustrated by the narration of the incest between Ruth and her father.

Ruth Foster Dead's father is the only black doctor in the town. Ruth is so obsessed with her father that her husband feels unqualified. For the husband, he believes that Ruth loves her father more than him, and treats Ruth violently. After Doctor Foster's death, Ruth's husband declares to have discovered her sucking her father's fingers in bed with the corpse. But later Ruth tells her son Milkman that she knelt at the bedside and kissed the only part of her father's body that was unaffected by the disease. The contradiction between husband and wife makes it hard for Milkman to find the truth, and so do readers. Therefore, it is difficult to tell whether the incestuous relationship between Ruth and her father is a fact or her husband's imagination.

In the traditional omniscient narrative, readers can make a clear judgement entirely relying on the implication of the narrator. By contrast, the narrator who disintegrates his or her authority, is willing to accentuate the significance of readers. The aforementioned elements exactly tally with the postmodern narrative concept of Toni Morrison who believes that the omniscience is no more than the imagination of mankind. Even if the narrator has the same perspective as the character, some events cannot be rationally explained due to the unknown motivation of the characters.

In other words, the writers of metafiction "often use anti-traditional techniques to weaken (not abandon) the omniscient and omnipotent writers or narrators, the complete endings and the definite explanations" (Chen \& Qu, 2013, p. 353). In Song of Solomon, the authority of the narrator is reduced by uncertain narratives. On one hand, the narrator is keen to tell the magical or incredible stories. On the other hand, she narrates carefully without judging the authenticity of the relevant event. For example, when it comes to the oddity that Pilate does not have the bellybutton, the narrator reports the feelings of Macon or other roles instead of making a direct statement. Besides, the narrator always maintains a neutral attitude towards this matter. In the traditional omniscient narrative, the narrator keeps his or her own authority by rejecting the unreal and supernatural things imaged by characters. Oppositely, the narrator in the novel written by Toni Morrison does not reprimand the illusory phenomenon, and does not use his or her own voice to tell the mysterious story as well. On this basis, it is the reader who is responsible for figuring out the veracity of the magical things.

As for Toni Morrison, her novels are aware of postmodern meta-narratives, including myth, legend, storytelling, the oral tradition, and African-American history. Compared to the realistic fiction which is identical with the orderly social reality, the writers of metafiction consider that the present society is a series of constructions rather than a permanent reality. Consequently, Morrison uses a kind of meta-language to construct a fictional form that is suitable for this reality. In general, metafiction reveals how the imaginative world is constructed in literary works, which helps to understand that the realistic world can be constructed in the same way.

\section{Indeterminacy: To Reveal the Essential Postmodern Narrative Feature}

According to Ihab Hassan, a notable literary theorist, indeterminacy is an essential feature of postmodern novels. Song of Solomon embodies this indeterminacy in the concept of flight. The epigraph of the novel, "the fathers may soar and the children may know their names," incarnates the theme of flight. "As a part of black folklore, 
flying is a supernatural fantasy of black people who aspire to escape from suffering and pursue for freedom" (Hu, 2013, p. 71). However, the symbolism of flight is ambiguous and indeterminate in this novel.

First, Solomon is happy for relieving from slavery by flying back to Africa, while his wife and children are filled with grief for being left behind. Based on this, flight epitomizes escape. Second, in the beginning of the novel, Mr. Smith jumps to put an end to his own life. In this case, flight means suicide. Next, Milkman's flight from Not Doctor Street represents a spiritual relief from his daily distress. Nonetheless, the African-Americans do not obtain the bliss and hope by flying. Moreover, flight can also be negatively explained with the connotation of escape, which means leaving the old world, thus bringing pain for those left behind. As shown above, the concept of flight highlights the indeterminacy of this novel.

In the same way, the surname of Milkman's family, Dead, has a double meaning, which reflects the indeterminacy as well. The family is called Dead in the white society, which indicates that the family has lost their real surname and their roots as well. The novel depicts the damaging effects of racism, that is, Milkman is dead both in terms of name and his personality before realizing the spiritual rebirth. Besides, during slavery period, the act of singing was a way for slaves to convey their own feelings and inspire others, thus completing their work on the plantation. Those songs they sang were about belief and hope, and the way to live with the spirit of God. In other words, the content of singing is a reference to both the period of slavery and the oral tradition in Africa, which shows a kind of indeterminacy. In addition, Pilate sings the old blues song, demonstrating the importance of the African oral tradition. This song, originally referring to Solomon, tells the story of the great-grandfather of Milkman. It also shows the history of Milkman's family, and urges Milkman to rebuild his spiritual bond.

What's more, "the significance of both Milkman's quest and the folktale his search is founded on are paradoxical" (Blake, 1980, p. 80). On one hand, Milkman obviously looks up to Solomon, saying that "He could fly! You hear me? My great-granddaddy could fly! Goddam!" (Morrison, 1977, p. 331). On the other, the principle of being responsible for others that Milkman must learn has been violated by Solomon. In this novel, this obvious contradiction or indeterminacy leads to doubts about the relationship between individuals and groups.

\section{Conclusion}

The intertextuality of Song of Solomon and the Bible exists between the lines of the novel and becomes an indispensable feature of postmodern narrative. By parodying the Bible and African mythic structure, the novel forms a gigantic narrative space inside and outside of the text. Furthermore, as a metafiction, Song of Solomon has the characteristic of self-reflection and at the same time shows its inclination to doubt the fictional form. As far as Morrison is concerned, both the Bible and black myths represent authority and certainty, which will give readers an expectation of order and ultimate meaning. But readers can not find an answer or the so-called truth in Song of Solomon. Based on this, the authority of an omniscient and omnipotent narrator melts away.

In a nutshell, in Song of Solomon, Tony Morrison uses the postmodern narrative to create a fictional world in which the meaning has never been assured and the question has never been answered, thus offering complex examinations of problems within the African-American community and probing into the future development of black people who were in a society full of racist trauma. The present analysis on the postmodern narrative features in Toni Morrison's Song of Solomon understands itself as complementary to the already existing body of African-American critical literature, providing references for relevant studies, national and international.

\section{Acknowledgements}

Research for the above paper has been supported by Project of Humanities and Social Sciences, Ministry of Education of the People's Republic of China: "A Study of Chinese Culture and its Images in US-American Newspapers in the New Media Era" (Project No. 19YJCZH162), University-Industry Collaborative Education Program, Ministry of Education of the People's Republic of China (Project No. 20190215002), and Fundamental Research Funds for the Central Universities (Project No. 2020MS056).

\section{References}

Blake, S. L. (1980). Folklore and Community in Song of Solomon. MELUS, 7(3), 77-82. https://doi.org/10.2307/467030

Chen, S. D., \& Qu, X. L. (2013). A History of American Literature. Beijing: Renmin University of China Press.

Farshid, S. (2015). The Crucial Role of Naming in Toni Morrison's 'Song of Solomon'. Journal of African American Studies, 19(3), 329-338. https://doi.org/10.1007/s12111-015-9301-5 
Guo, L. F., \& Yang, X. L. (2017). Counteraction and Contest under Submission and Identification: Parody of the Bible in Toni Morrison's Song of Solomon. Journal of Xichang College (Social Science Edition), 29(1), 69-71.

Harris, A. L. (1980). Myth as Structure in Toni Morrison's Song of Solomon. MELUS, 7(3), 69-76. https://doi.org/10.2307/467029

Hu, J. (2013). A Narration Bereft of Authority-A Study on the Postmodern Narrative Elements in Song of Solomon. Foreign Studies, 1(4), 68-72, 107.

Hutcheon, L. (1988). A Poetics of Postmodernism: History, Theory, Fiction. New York: Routledge.

Middleton, J. I. (1993). Orality, Literacy, and Memory in Toni Morrison's Song of Solomon. College English, 55(1), 64-75. https://doi.org/10.2307/378365

Morrison, T. (1977). Song of Solomon. New York: NAL.

Shirvani, H. (1994). Postmodernism: Decentering, Simulacrum, and Parody. American Quarterly, 46(2), 290-296. https://doi.org/10.2307/2713344

Story, R. (1989). An Excursion into the Black World: The 'Seven Days' in Toni Morrison's Song of Solomon. Black American Literature Forum, 23(1), 149-158. https://doi.org/10.2307/2903998

Tang, H. M. (2004). On the Folk Song of Song of Solomon. Foreign Literature Studies, 1, 109-114, 174.

Wang, N. (2013). Introduction: Historicizing Postmodernist Fiction. Narrative, 21(3), 263-270. https://doi.org/10.1353/nar.2013.0017

Xu, W. P. (2003). The Estranged Relationships in Song of Soloman. Academic Exchange, 3, 149-152.

\section{Copyrights}

Copyright for this article is retained by the author, with first publication rights granted to the journal.

This is an open-access article distributed under the terms and conditions of the Creative Commons Attribution license (http://creativecommons.org/licenses/by/4.0/). 